\title{
Allozyme variability of brown trout (Salmo trutta L.) populations across the Rhenanian-Danubian watershed in southwest Germany
}

\author{
MICHAEL RIFFEL*, VOLKER STORCH \& ARND SCHREIBER \\ Zoologisches Institut I, Universität Heidelberg, Im Neuenheimer Feld 230, D-69120 Heidelberg, Germany
}

\begin{abstract}
Using horizontal agarose thin layer gel electrophoresis, 35 allozyme loci were screened in 233 brown trout (Salmo trutta L.) from 11 populations in southwest Germany across the RhenanianDanubian watershed. Polymorphism was found at $10 \mathrm{loci}$, with stocked populations exhibiting significantly increased polymorphism compared with unmanaged stocks $(P=0.219$ vs. $P=0.132$ ). Standard genetic distances between populations from different brooks averaged at $D=0.01$. Of the total gene diversity of $G_{\mathrm{ST}}=0.198$, only a negligible amount partitioned between Rhenanian and Danubian drainages $\left(G_{\mathrm{GT}}=0.010\right)$. One biallelic locus, $L D H-5^{*}$, indicated river-specific allele frequencies, with the allele $L D H-5^{*} 105$ being markedly more frequent within the Danubian drainage system. In contrast, $L D H-5^{*} 100$ was close to fixation in the Rhenanian populations. This locus suggests a phylogeographical relationship of Danubian trout from southwest Germany with brown trout from southeastern Europe rather than with conspecifics of adjacent Rhenanian origin.
\end{abstract}

Keywords: allozyme polymorphism, phylogeography, resident brown trout, Salmo trutta L., stocking.

\section{Introduction}

The complex genetic structure of brown trout (Salmo trutta L.) populations, as identified by protein electrophoresis, has been emphasized by a number of research groups. The review article by Ferguson (1989) reported percentages of polymorphic allozyme loci ranging from 0.000 to 0.348 (average $\mathrm{P}=0.160$ ), and average observed heterozygosity from 0.000 to 0.122 (mean $H_{\mathrm{o}}=0.047$ ) in populations from France, Greece, Iceland, Ireland, Scandinavia, the UK, USA and from the former USSR. Further data have been published since from Spain (Garcia-Marin et al., 1991; Martinez et al., 1993), and Denmark (Møller Hansen et al., 1993). On a regional scale, there is only a weak correlation of genetic distances between local trout populations and geographical distances separating the respective stocks, suggesting a complex metapopulation structure for the species (Ryman, 1983; Ferguson, 1989). On a larger geographical scale, substantial differences have been reported between Mediterranean and Atlantic populations of France (Krieg \& Guyomard, 1985) and between brown trout from the

\footnotetext{
${ }^{*}$ Correspondence.
}

White, the Baltic, the Caspian, and the Black Seas from within the former USSR (Osinov, 1984).

The population genetics of Central European brown trout has been largely neglected despite the biogeographical interest implied, with a principal watershed of Continental Europe, separating the Rhenanian and Danubian drainage complexes, extending through southwestern Germany. The German state of BadenWürttemberg $\left(35750 \mathrm{~km}^{2}\right)$ includes the source region of the Danube that has been subject to inroads by the Rhine system since Tertiary times due to the latter's higher erosion capacity (Wagner, 1963; Mader, 1978). The Rhenanian drainage covers about 78 per cent of the total area of Baden-Württemberg (Borcherdt, 1991).

Danubian (i.e. Black Sea) trout have been described as a subspecies, Salmo trutta labrax Pallas 1811. This taxon's validity has been questioned (Balon, 1968) but has since been re-established after finding significantly higher numbers of gill rakers in specimens from northeastern Turkey (Lelek, 1988). The western limit of the range of Salmo trutta labrax remains unknown. Allozymes have been analysed in brown trout of Black Sea origin from within the former USSR (Osinov, 1984) and from Greece (Karakousis \& Triantaphylli- 
dis, 1990), without direct reference to Rhenanian (i.e. North Atlantic) populations. Comparison of DNA sequences of the mitochondrial control region of brown trout throughout Europe revealed significant differentiation between populations of Danubian and Rhenanian origins. However, only one population from Germany (Baden-Wurttemberg) was examined (Bernatchez et al., 1992).

Along with adjacent Alsace, where the first documented trout hatchery dates back to 1842 (Müller, 1956), Baden-Wuirttemberg has one of the longest traditions of brown trout breeding and stocking in Europe. Today, stocking is widely considered an obligation to comply with fishery lease contracts. Rarely has the origin of hatchery trout been taken into consideration. As elsewhere (Barbat-Leterrier et al., 1989; Hindar et al., 1991), autochthonous populations are threatened if not already lost. Even efforts to preserve local indigenous populations, e.g. trout spawning in acid, high-altitude streams of the Black Forest, suffer from ignorance about the population differentiation of the region's salmonids.

The present investigation contributes data on the population structure of brown trout across the watershed separating the catchment areas of the Rhine and the Danube rivers. Supporting initial efforts by the region's authorities, and local fishing cooperatives, to base the traditionally intensive trout management on ecologically sounder principles, we analysed the genetic structure of both heavily stocked populations and presumed 'autochthonous' unmanaged populations, for which regular stocking could be excluded for the past few decades at least.

\section{Materials and methods}

\section{Populations}

Selection criteria for study populations included their natural reproduction, and the confirmation by local users that in all populations sampled no stocking had occurred for at least 3 years (only age classes younger than 3 years were collected).

Depending on the stocking incidence, the chosen populations could be arranged into two groups: unmanaged populations experiencing occasional or no stocking for the past few decades and populations that were intensively stocked annually except for the past 3 years. Details of trout management were obtained from the local authorities of the fishing cooperatives. Some of the sampled habitats were isolated by weirs, tunnels or natural barriers which prevent upstream migration of brown trout. Sample localities (mapped in Fig. 1), the respective river system, sample sizes, stocking incidence and isolation conditions are listed in Table 1.

\section{Sample preparation and allozyme electrophoresis}

Fish were collected in August/September of 1992 and 1993. Tissue samples from skeletal muscle, liver and eye were taken and stored at $-70^{\circ} \mathrm{C}$ immediately after sacrificing the fish. Tissues were sonicated in $50 \mathrm{~mm}$ Tris/HCl pH 7.5 (including $10 \mathrm{~mm} \quad \beta$-mercaptoethanol), and the lysates applied to $1 \mathrm{~mm}$ thin horizontal agarose gels (SEAKEM LE agarose, FMC BioProducts, Rockland, USA). With the following exceptions, the electrophoretic buffers chosen were those recommended by Harris \& Hopkinson (1976): MPI was resolved in $150 \mathrm{~mm}$ sodium phosphate buffer $\mathrm{pH}$ 6.6 (gel buffer: 1:10 dilution of tray solution). A buffer system (tray buffer: $0.1 \mathrm{~m} \mathrm{NaOH} / 0.3 \mathrm{~m}$ sodium borate, gel buffer: $76 \mathrm{~mm}$ Tris, $5 \mathrm{~mm}$ citric acid, $15 \mathrm{~mm}$ sodium borate, $5 \mathrm{~mm} \mathrm{NaOH}, \mathrm{pH} 8.5$ ) modified after Taggart $e t$ al. (1981) served to resolve GPI, CK and LDH. A buffer system by Schaal \& Anderson (1974) (tray buffer: $0.233 \mathrm{M}$ Tris/ $0.086 \mathrm{M}$ citric acid, gel buffer: $1: 30$ dilution of electrode buffer, $\mathrm{pH} 6.0$ ) was used for $\mathrm{AH}$, and the TP-buffer system (tray buffer: $0.15 \mathrm{M}$ trisodium citrate $/ 0.15 \mathrm{M}$ citric acid, gel buffer: $1: 40$ dilution of electrode buffer, $\mathrm{pH}$ 6.3) by Guyomard \& Krieg (1983) for the electrophoresis of MEP. Zymogram staining followed the recipes by Aebersold et al. (1987).

Gels were stained for (E.C. numbers and locus designations in parentheses): acid phosphatases (3.1.3.2) $\left(A C P-1^{*}, A C P-2^{*}\right)$, aconitases (4.2.1.3) $\left(A H-1^{*}, A H\right.$ $\left.2^{*}\right)$, adenosindeaminases (3.5.4.4) (ADA-1*, $\left.A D A-2^{*}\right)$, alanine aminotransferase (2.6.1.2) $\left(A L A T-1^{*}\right)$, aspartate aminotransferases (2.6.1.1.) (sAAT-1,2*, sAAT-3*), creatine kinases (2.7.3.2) (CK-1*,CK-2*), esterase (3.1.1.1) $\left(E S T-2^{*}\right)$, glucose-6-phosphate isomerases (5.3.1.9) (GPI-1*, GPI-2*, GPI-3*), glycerol-3-phosphate dehydrogenase (1.1.1.8) (G3PDH-2*), guaninedeaminase $(3.5 .4 .3)\left(G D A^{*}\right)$, isocitrate dehydrogenase (1.1.1.42) $\left(I D H P-2^{*}\right)$, lactate dehydrogenases (1.1.1.27) ( $L D H-I^{*}, L D H-2^{*}, L D H-3^{*}, L D H-4^{*}$, $\left.L D H-5^{*}\right)$, lactoylglutathione lyase $(4.4 .1 .5)\left(L G L^{*}\right)$, malate dehydrogenases (1.1.1.37) (MDH-1, $M D H-2)$, malic enzymes (1.1.1.40) $\left(M E P-1^{*}, M E P-2^{*}, M E P-3^{*}\right)$, mannose-6-phosphate isomerase (5.3.1.8) (MPI-2*), phosphoglucomutase (5.4.2.2) $\left(P G M-1^{*}\right)$, phosphogluconate dehydrogenase (1.1.1.44) $\left(P G D H^{*}\right)$, nucleoside phosphorylase (2.4.2.1) $\left(P N P^{*}\right)$ and superoxide dismutase (1.15.1.1) ( $S O D-2 *)$. Enzyme nomenclature follows Shaklee et al. (1990). As enumeration of loci in brown trout is not fully standardized in multilocus isozyme systems, we chose to designate their loci in agreement with Allendorf et al. (1977), Taggart et al. (1981) and Guyomard \& Krieg (1983). The only exception was AAT (expressed in liver extracts) which 
Fig. 1 Major river systems, collection sites and geographical variation in the frequencies of two alleles at the $L D H$ $5^{*}$ locus of brown trout from BadenWirttemberg (Germany). The Danubian drainage system is delimited by a dotted line.

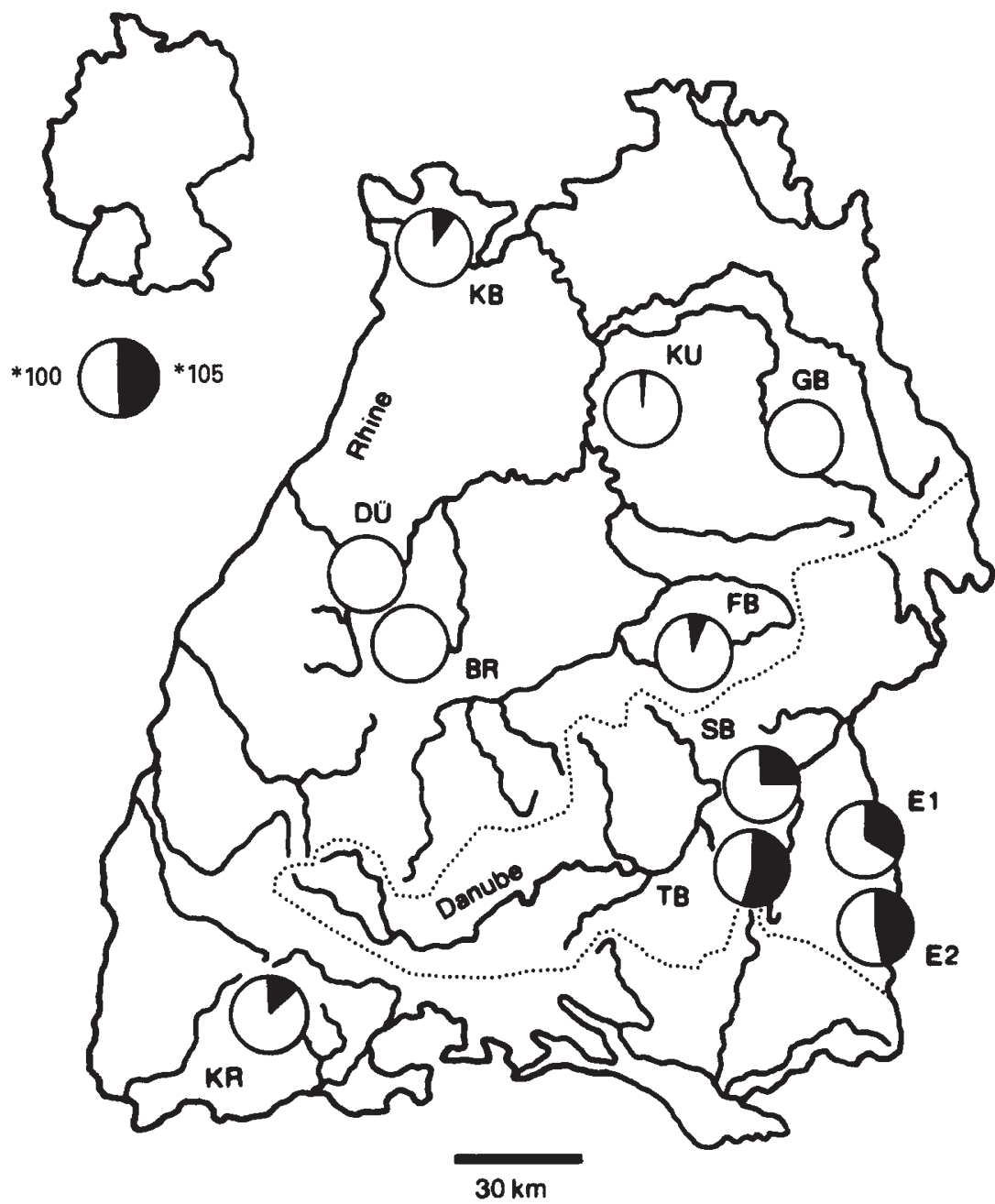

Table 1 Sample locations, river systems, number of brown trout taken, recorded previous stocking incidence (before 1989) and feasibility of upstream migration towards the sample location

\begin{tabular}{|c|c|c|c|c|c|}
\hline Stream & Abbr. & River system & Sample size & Stocking & Isolation \\
\hline Gruppenbach & GB & Neckar-Rhine & 20 & Occasional & Complete \\
\hline Kurzach & $\mathrm{KU}$ & Neckar-Rhine & 29 & Regular & No \\
\hline Fischbach & FB & Neckar-Rhine & 20 & Occasional & Partial \\
\hline Katzenbach & $\mathrm{KB}$ & Neckar-Rhine & 16 & Regular & No \\
\hline Dürreychbach & DÜ & Neckar-Rhine & 22 & No & No \\
\hline Brotenau & BR & Neckar-Rhine & 23 & No & No \\
\hline Krummenbach & KR & Rhine & 20 & No & No \\
\hline Eckbach & $\mathrm{E} 1$ & Iller-Danube & 23 & No & Complete \\
\hline Eckbach & $\mathrm{E} 2$ & Iller-Danube & 23 & Regular & No \\
\hline Schorrenbach & SB & Riss-Danube & 16 & No & Partial \\
\hline Tiefentalbach & TB & Riss-Danube & 21 & No & No \\
\hline
\end{tabular}


was designated here to be coded by $s A A T-3^{*}$ instead of $s A A T-4^{*}$ (Taggart et al., 1981).

The most common allele at each polymorphic locus was denoted as ' 100 ' whereas variant alleles were characterized by numbers reflecting their electrophoretic mobility relative to the most common allele.

\section{Statistical analysis}

Allele frequencies were counted directly from the zymograms. In $C K-1^{*}$, the distinction between heterozygotes $(C K-1 * 100 / 115)$ and one of the homozygote genotypes $(C K-1 * 100 / 100)$ was not possible. Therefore, the frequency of the variant allele was calculated (assuming Hardy-Weinberg equilibrium) as the square root of the frequency of the scorable homozygotes $\left(C K-1^{*} 115 / 115\right)$ (Allendorf et al., 1976). Because of the remaining uncertainty underlying this procedure, this locus was excluded from further statistical analysis. Chi-square contingency tests were employed to check statistical significance of differences in allele frequencies between populations, and possible deviations of the observed numbers of genotypes from Hardy-Weinberg expectations. To assess the genetic differentiation of the populations studied, $G_{\mathrm{ST}}$ and $G_{\mathrm{GT}}$ were estimated following Chakraborty \& Leimar (1987). Calculation of Nei's (1978) standard genetic distance, and the construction of an UPGMA tree was performed with the PHYLIP software package (Felsenstein, 1989).

\section{Results}

The electrophoretic investigation of 20 enzyme systems from skeletal muscle, liver and eye of 233 brown trout from 11 populations in southwest Germany revealed 35 scorable protein-coding loci. Ten of these scorable loci proved polymorphic. In addition, fumarase (E.C. 4.2.1.2.) and xanthine oxidase (E.C. 1.2.3.2) yielded zymogram variability for which an unambiguous genetic interpretation was impossible. All polymorphic loci scored were codominantly expressed. Disregarding fumarase and xanthine oxidase, the overall polymorphism $(\mathrm{P})$ amounted to 0.286 , varying from 0.057 to 0.257 between sample populations. The following variant alleles were found at polymorphic loci, in addition to the common allele: GPI-3*110, G3PDH-2*65, sAAT-1,2*130, CK-1*115, SOD-2*55, SOD $-2 * 130, \quad I D H P-2 * 70, \quad M P I-2 * 110$, $s M D H-2 * 150, s A A T-3 * 70$ and $L D H-5 * 105$. Not a single population studied contained all of the variant alleles. Two private alleles, SOD-2*55 and $1 D H P-2 * 70$, were restricted to single populations, Katzenbach $(\mathrm{KB})$ and Gruppenbach $(\mathrm{GB})$, respectively. Although refer- ence samples were not available, the relative mobilities published for allozyme alleles from other European brown trout populations suggest identity of the alleles encountered in Baden-Württemberg to those described previously (Ferguson, 1989; Garcia-Marin et al., 1991; Martinez et al., 1993). The average expected heterozygosity $\left(H_{\mathrm{e}}\right)$ ranged from 0.0193 to 0.0517 between populations (mean $=0.0376$ ). Allele frequencies, expected heterozygosities and percentages of polymorphism are presented in Table 2.

Tests for possible deviations from Hardy-Weinberg equilibrium of genotype numbers did not produce significant evidence for disequilibria in 43 comparisons of observed and expected genotype numbers. This observation applies both to unmanaged and to intensively stocked populations. Significant differences in allele frequencies between local populations were frequent, as is evident from Table 3 which lists the $\chi^{2}$ values of those comparisons calculated separately for each polymorphic locus, and then summed over all loci. Pairwise comparison between brooks of these combined $\chi^{2}$ values of the allele frequency differentiation of all polymorphisms in any population yielded only four nonsignificant comparisons out of a total of 55 population pairs (Table 3 ). Gene diversity analysis indicated that 19.8 per cent of the total variation observed resulted from differences between the populations inhabiting the 11 streams $\left(G_{\mathrm{ST}}=0.198\right)$. Hierarchical gene diversity analysis was performed to partition the genetic variability between Danubian and Rhenanian populations. The genetic variability distributed between these two major groups of subpopulations amounted to a mere 1.0 per cent $\left(G_{\mathrm{GT}}=0.010\right)$, whereas the gene diversity between the subpopulations collected from waters within each drainage system measured 18.9 per cent $\left(G_{\mathrm{SG}}=0.189\right)$.

The mean standard genetic distance between trout from different streams was $D=0.010$ (range $=$ 0.0011-0.0288; Table 3). The UPGMA dendrogram based on these distances does not reveal any correlation between geographical proximity of streams and genetic distances between trout inhabiting them (Fig. 2 ); neither is a dichotomy of the genetic distances between the Rhenanian and Danubian drainages observed.

A single locus, $\mathrm{LDH}-5^{*}$, was exceptional in indicating an obvious geographical pattern, with the allele $L D H-5^{*} 105$ being distinctly more frequent within the Danubian drainage system (Fig. 1). Allele frequencies at the locus $L D H-5^{*}$ differed significantly when comparing all trout from Rhenanian and Danubian origins $\left(\chi_{1}^{2}=101.94, P<0.001\right)$. To test the evenness of $\mathrm{LDH}$ allele distribution among individual populations, an additional $\chi^{2}$ test was based on pairwise 
Table 2 Observed frequencies of variant alleles (common allele, ${ }^{*} 100$, omitted), sample sizes, estimates of expected heterozygosity $\left(H_{e}\right)$ and proportions of polymorphic loci $(\mathrm{P})$ in brown trout populations from Baden-Württemberg (Germany)

\begin{tabular}{|c|c|c|c|c|c|c|c|c|c|c|c|}
\hline \multirow[b]{2}{*}{ Allele } & \multicolumn{11}{|c|}{ Populations studied } \\
\hline & GB & KU & FB & KB & DÜ & $\mathrm{BR}$ & KR & E1 & E2 & SB & TB \\
\hline$G P I-3 * 110$ & 0.25 & 0.03 & 0.23 & 0.06 & 0.48 & 0.25 & 0.03 & 0 & 0.11 & 0 & 0.09 \\
\hline G3PDH-2*65 & 0 & 0.09 & 0 & 0.12 & 0 & 0 & 0 & 0 & 0.02 & 0.06 & 0.07 \\
\hline$S A A T-1,2 * 130$ & 0 & 0 & 0 & 0.03 & 0 & 0 & 0 & 0.20 & 0 & 0 & 0 \\
\hline$C K-1 * 115$ & 0 & 0.42 & 0.86 & 0.75 & 1.00 & 0.83 & 0.77 & 0.29 & 0.36 & 0.43 & 0.38 \\
\hline SOD- $2 * 55$ & 0 & 0 & 0 & 0.06 & 0 & 0 & 0 & 0 & 0 & 0 & 0 \\
\hline$S O D-2 * 135$ & 0.30 & 0.07 & 0 & 0 & 0 & 0 & 0 & 0 & 0 & 0 & 0 \\
\hline$I D H P-2 * 70$ & 0.20 & 0 & 0 & 0 & 0 & 0 & 0 & 0 & 0 & 0 & 0 \\
\hline MPI-2*110 & 0.08 & 0.19 & 0.03 & 0.22 & 0 & 0 & 0.26 & 0 & 0.04 & 0.25 & 0.43 \\
\hline$s M D H-2 * 150$ & 0 & 0.19 & 0.05 & 0.16 & 0.50 & 0.09 & 0.18 & 0.59 & 0.30 & 0 & 0 \\
\hline$s A A T-3^{*} 70$ & 0.35 & 0.29 & 0 & 0.62 & 0 & 0.17 & 0.20 & 0 & 0.20 & 0.09 & 0.19 \\
\hline LDH-5*105 & 0 & 0.02 & 0.08 & 0.10 & 0 & 0 & 0.13 & 0.33 & 0.48 & 0.25 & 0.55 \\
\hline$N$ & 20 & 29 & 20 & 16 & 22 & 23 & 20 & 23 & 23 & 16 & 21 \\
\hline$H_{\mathrm{e}}$ & 0.0501 & 0.0417 & 0.0193 & 0.0517 & 0.0294 & 0.0241 & 0.0377 & 0.0366 & 0.0456 & 0.0302 & 0.0466 \\
\hline $\mathrm{P}$ & 0.143 & 0.229 & 0.143 & 0.257 & 0.057 & 0.114 & 0.171 & 0.114 & 0.171 & 0.143 & 0.171 \\
\hline
\end{tabular}

$H_{e}$ is based on 34 loci (excluding $C K-1^{*}$ ) while $\mathrm{P}$ is based on 35 loci.

Abbreviations for sample localities are those given in Table 1.

Table 3 Genetic differentiation of brown trout populations from Baden-Württemberg (Germany)

\begin{tabular}{|c|c|c|c|c|c|c|c|c|c|c|c|}
\hline & GB & $\mathrm{KU}$ & FB & KB & DÜ & $\mathrm{BR}$ & $\mathrm{KR}$ & E1 & E2 & SB & TB \\
\hline GB & & 0.0062 & 0.0080 & 0.0092 & 0.0173 & 0.0053 & 0.0087 & 0.0255 & 0.0154 & 0.0109 & 0.0191 \\
\hline $\mathrm{KU}$ & $36.98_{(8)}^{* * *}$ & & 0.0056 & 0.0038 & 0.0132 & 0.0037 & 0.0012 & 0.0133 & 0.0084 & 0.0042 & 0.0122 \\
\hline FB & $34.53_{(7)}^{* * *}$ & $29.99_{(7)}^{* * *}$ & & 0.0146 & 0.0082 & 0.0011 & 0.0046 & 0.0136 & 0.0084 & 0.0043 & 0.0135 \\
\hline KB & $35.36_{(10)}^{* * * *}$ & $14.61_{(9)}^{\mathrm{NS}}$ & $48.44_{(8)}^{* * *}$ & & 0.0233 & 0.0098 & 0.0061 & 0.0224 & 0.0121 & 0.0105 & 0.0145 \\
\hline DÜ & $67.45_{(6)}^{* * *}$ & $50.66_{(7)}^{* * *}$ & $25.02_{(4)}^{* * * *}$ & $72.37_{(8)}^{* * *}$ & & 0.0076 & 0.0131 & 0.0118 & 0.0138 & 0.0189 & 0.0288 \\
\hline BR & $28.66_{(6)}^{* * *}$ & $33.64_{(7)}^{* * *}$ & $9.47(5)$ & $36.21_{(8)}^{* * *}$ & $27.08_{(3)}^{* * *}$ & & 0.0043 & 0.0150 & 0.0090 & 0.0062 & 0.0161 \\
\hline $\mathrm{KR}$ & $44.45_{(7)}^{* * *}$ & $14.13_{(7)}^{*}$ & $22.68_{(5)}^{* * *}$ & $18.68_{(8)}^{*}$ & $56.10_{(5)}^{* * *}$ & $27.62_{(5)}^{* * *}$ & & 0.0110 & 0.0059 & 0.0019 & 0.0076 \\
\hline E1 & $102.60_{(8)}^{* * *}$ & $70.41_{(8)}^{* * *}$ & $46.73_{\{5\}}^{* * *}$ & $71.35_{(8)}^{* * *}$ & $49.18_{(4)}^{* * *}$ & $64.61_{(5)}^{* * *}$ & $40.96_{(6)}^{* * *}$ & & 0.0062 & 0.0144 & 0.0208 \\
\hline E2 & $62.78_{(8)}^{* * * *}$ & $39.80_{(7)}^{* * *}$ & $32.85_{(6)}^{* * *}$ & $34.30_{(8)}^{* * *}$ & $51.74_{(6)}^{* * *}$ & $35.58_{(6)}^{* * *}$ & $12.05_{(6)}^{N S S}$ & $29.29_{(7)}^{* * *}$ & & 0.0065 & 0.0077 \\
\hline SB & $39.81_{(7)}^{* * *}$ & $20.39_{(7)}^{* *}$ & $20.18_{(6)}^{* * *}$ & $25.86_{(8)}^{* * *}$ & $61.58_{(6)}^{* * * *}$ & $30.76_{(5)}^{* * *}$ & $6.744_{(6)}^{N S}$ & $45.52_{(6)}^{* * *}$ & $22.55_{(6)}^{* * *}$ & & 0.0043 \\
\hline TB & $61.21_{(7)}^{* * *}$ & $53.14_{(7)}^{* * * *}$ & $58.01_{(6)}^{* * *}$ & $34.64_{(8)}^{* * *}$ & $88.69_{(6)}^{* * *}$ & $64.47_{(6)}^{* * *}$ & $21.64_{(6)}^{* * *}$ & $70.64_{(7)}^{* * *}$ & $33.30_{(6)}^{* * * *}$ & $17.74_{(5)}^{* *}$ & \\
\hline
\end{tabular}

Above diagonal: Nei's (1978) standard genetic distances between populations. Below diagonal: $\chi^{2}$ values of pairwise contingency tests for homogeneity of allelic frequencies between populations studied (degrees of freedom in parentheses; $\left.{ }^{*} P \leqslant 0.05,{ }^{* *} P \leqslant 0.01,{ }^{* * *} P \leqslant 0.001\right)$.

comparisons of all brook stocks: 23 out of 28 possible comparisons of $\mathrm{LDH}-5^{*}$ allele frequencies of Rhenanian with Danubian populations proved highly significant $(P<0.01)$. In contrast, intradrainage comparisons of allelic homogeneity of Rhenanian (20 comparisons) and Danubian populations (6 comparisons) did not reveal differences at the $L D H-5^{*}$ locus at the same level of significance $(P>0.01)$. A mere three pairwise comparisons of populations (out of 26) from brooks within a single drainage system $(\mathrm{KR} \times \mathrm{BR}$; $\mathrm{SB} \times \mathrm{E} 2$; $\mathrm{SB} \times \mathrm{TB})$ produced significant differentiation $(P<0.05)$ of frequencies at the $L D H-5^{*}$ locus.
Three populations experiencing regular stocking, Eckbach (E2), Kurzach (KU) and Katzenbach (KB), displayed significantly elevated polymorphism $(P=0.219)$ when compared with unmanaged populations $(\mathrm{P}=0.132)$ (Mann-Whitney test, $P<0.05)$. The value for the absolute gene diversity $\left(G_{\mathrm{ST}}=0.099\right)$ was lower among the three stocked populations than that obtained from the remaining stocks $\left(G_{\mathrm{ST}}=0.21\right)$, indicating that regular stocking reduces the betweenpopulations component of genetic variation. Accordingly, $H_{\mathrm{T}}$ (i.e. expected heterozygosity of a putative panmictic population comprising all studied 


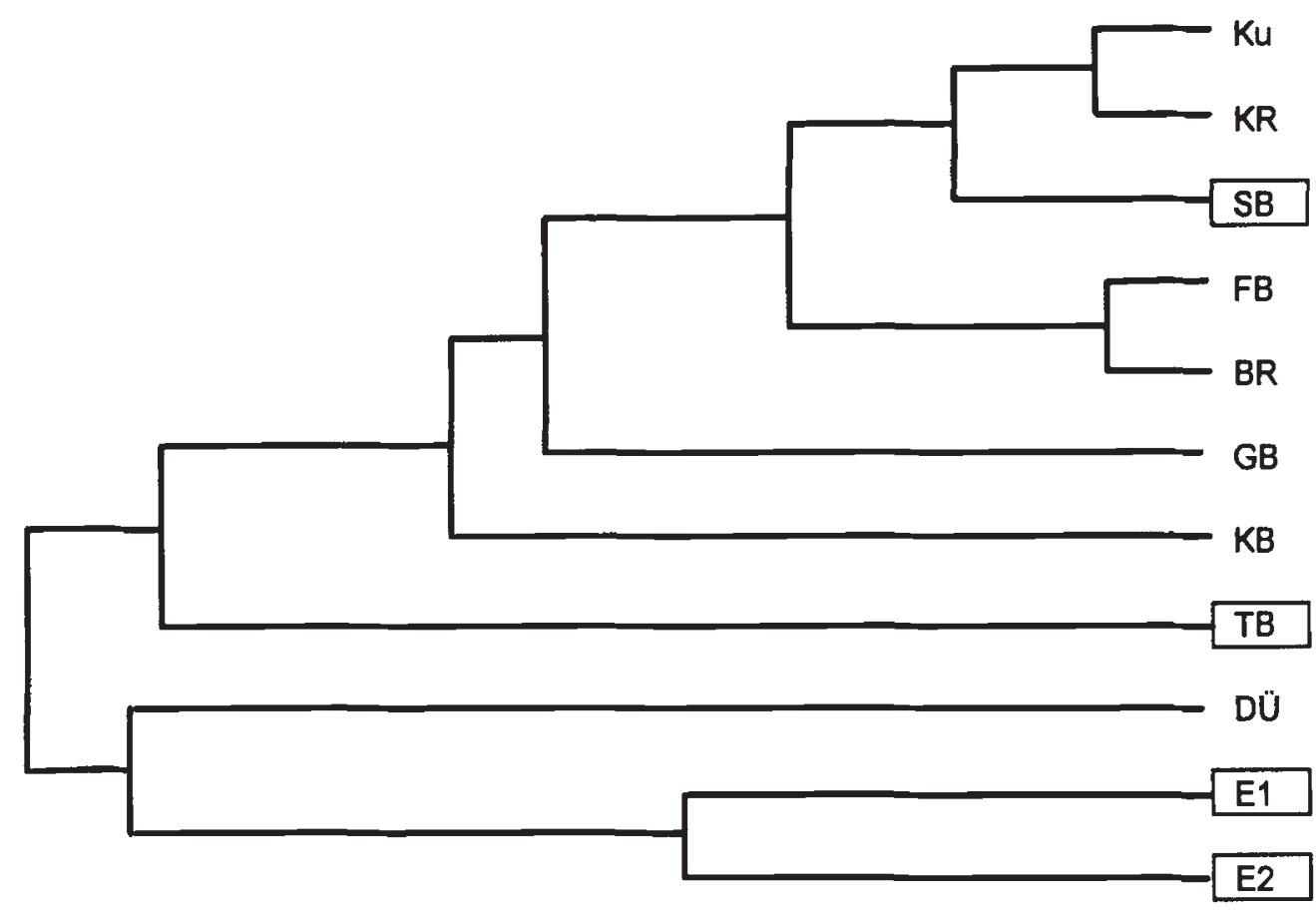

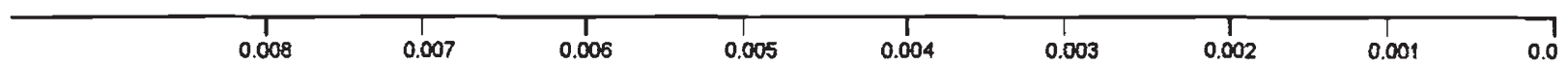

Fig. 2 UPGMA dendrogram clustering Nei's (1978) standard genetic distances separating brown trout populations from BadenWuirttemberg on the basis of 34 allozyme loci $\left(C K-1^{*}\right.$ omitted $)$. Populations inhabiting the Danube drainage systems are marked by a box.

trout) was higher in stocked populations than in unmanaged stocks $\left(H_{\mathrm{T}}=0.051\right.$ vs. $\left.H_{\mathrm{T}}=0.043\right)$. The between-population component of gene diversity $\left(D_{\mathrm{ST}}\right)$, however, is much lower in these populations than in the populations experiencing no management.

\section{Discussion}

The proportion of polymorphic loci (mean: $\mathrm{P}=0.156$ ), and expected heterozygosities (mean: $H_{\mathrm{e}}=0.376$ ), of brown trout from southwestern Germany fit well into the range of values reported for the species (Ferguson, 1989; Skaaia, 1992). In Fischbach (FB), one of those four populations where low values of $H_{\mathrm{e}}$ were found $\left(H_{\mathrm{e}}=0.0193 ; \mathrm{P}=0.143\right)$, an oilspill had caused a population bottleneck in 1981. Another low heterozygosity stock, Schorrenbach (SB) $\left(H_{\mathrm{e}}=0.0302\right.$; $\mathrm{P}=0.143$ ) represented the smallest population in the study, with 43 , mostly immature, trout recorded within a $300 \mathrm{~m}$ stretch of the stream. As most of the variant alleles were found to occur at low frequencies in the populations, genetic drift could easily result in low levels of variation.

Two populations exhibiting low polymorphism and low expected heterozygosity values, Dürreychbach
(DÜ) $\left(H_{\mathrm{e}}=0.0294 ; \mathrm{P}=0.057\right)$ and Brotenau (BR) $\left(H_{\mathrm{e}}=0.0241 ; \mathrm{P}=0.114\right)$, inhabited brooks on acid sandstone bedrock which suffered from additional acidification from air pollution. Since the most acidsensitive ontogenetic stages of brown trout are those from freshly fertilized ova to yolk sac fry (Daye \& Garside, 1979), only a small proportion of ova is likely to hatch, enforcing annual bottlenecks during snow melt. The final population displaying reduced polymorphism, Eckbach (E1) $\left(H_{\mathrm{e}}=0.0366 ; P=0.114\right)$, is isolated by a weir preventing immigration, and has never been stocked. Lack of gene flow concomitant with small effective population size resulted in a loss of genetic variation.

Our $G_{\mathrm{ST}}$ value $\left(G_{\mathrm{ST}}=0.198\right)$ proved lower than that found in brown trout from France (Krieg \& Guyomard, 1985), Greece (Karakousis \& Triantaphyllidis, 1990), Spain (Garcia-Marin et al., 1991; Martinez et al., 1993), Britain, Ireland, Norway, Sweden and Iceland (Ferguson, 1989), demonstrating that partitioning of gene diversity in southwest Germany differed from the situation observed in those quoted populations. Only Danish populations in tributaries of Lake Hald revealed still lower $G_{\mathrm{ST}}$ values $\left(G_{\mathrm{ST}}=0.047\right.$ ) (Møller Hansen et al., 1993), whereas $G_{\mathrm{ST}}=0.11$ was observed 
for Danish brown trout from the Limfjord catchment (Landbo \& Persson, 1987 cited in Møller Hansen et al., 1993). These low $G_{\mathrm{ST}}$ values were attributed to the small sampling areas (Møller Hansen et al., 1993).

Various genetic consequences of stocking have been observed (Hindar et al., 1991; Moran et al., 1991; Martinez et al., 1993). Depending on the trout released, stocking may result in a decline, or an increase, of genetic variance both between and within populations (Nelson \& Soulé, 1987). Germany has a long stocking tradition to compensate for population declines of brown trout caused by various anthropogenic factors. There are no populations left for which stocking in the past or immigration by released fish can be totally excluded. Our results indicate genetic introgression of hatchery brown trout into natural populations which also has been reported from France (Barbat-Leterrier et al., 1989), Ireland (Taggart \& Ferguson, 1986) and Britain (Hauser et al., 1991). The intensively stocked populations clearly exhibited elevated genetic variability within the populations which is in accordance with expectations based on the varied origin of the hatchery stocks. It is common practice to acquire fish from different trout hatcheries over the years to obtain 'fresh blood'.

However, our genetic distances between local populations (mean: $D=0.01$ ), although falling in the range of published results (Ferguson, 1989), cluster towards their lower extreme. A decrease of genetic differentiation between trout populations in southern Germany as a result of massive stocking is a plausible inference, although the observed reduction of $G_{\mathrm{ST}}$ value in managed populations did not prove statistically significant. Without regular stocking, the between-populations component of genetic variation increases, and polymorphism decreases, possibly indicating the effects of genetic drift. Accordingly, the relatively low differentiation of brown trout observed across the main Central European watershed need not necessarily reflect the natural prestocking situation.

No correspondence between genetic and geographical distance could be revealed when considering all loci in the study. Neither the hierarchical gene diversity analysis nor the genetic distances suggest a strong divergence between Rhenanian and Danubian trout.

In contrast, polymorphism at one locus, $\mathrm{LDH}-5^{*}$, showed significant differentiation between these two major river drainages. Highly significant differences in allele distribution between Rhenanian and Danubian populations of brown trout were observed in most of the 28 possible pairwise comparisons of brooks $(P<0.01)$. This is a difference from intradrainage comparisons of allele frequencies which revealed merely three instances of significant differentiation $\langle P<0.05)$ between two populations (out of 26 possible comparisons), involving the population pairs $\mathrm{KR} \times \mathrm{BR}$, $\mathrm{SB} \times \mathrm{E} 2$ and $\mathrm{SB} \times \mathrm{TB}$. In this context, it is interesting to note that tiny Schorrenbach (SB) harbours the smallest of our Danubian study populations for which a reduced level of heterozygosity has been demonstrated. It is plausible to infer that genetic drift has affected the $L D H-5^{*} 105$ polymorphism. Trout from Krummenbach (KR) represent one of the most abundant unstocked populations which argues against stochastic influences on a biallelic system with frequencies as we found in $\mathrm{LDH}-5^{*}$. Krummenbach is a tributary of Wutach river, a contemporary affluent of the Rhine, although it formed part of the Danubian system during the Pleistocene (Hantke, 1993). Thus, it is tempting to infer affinity of Krummenbach trout with Danubian stock.

Genetic drift evidently constituting a prominent evolutionary mechanism in brown trout, this distribution could be a mere product of chance. However, this possibility appears to be very unlikely if one recalls that there was not a single homozygote $\mathrm{LDH}-5^{*} 105 / 105$ out of 150 trout from the Rhenanian drainage system whereas among the 83 trout of Danubian origin the total number of homozygotes found was 17 , spread over all Danubian populations. If recent genetic drift is obviously not responsible for the observed pattern, allele distribution at the locus $L D H-5^{*}$ might be affected by natural selection or by phylogeography. This LDH locus, which is expressed in fishes' eyes, has two codominant alleles in brown trout which have been designated as $L D H-5^{*} 100$ and $L D H-5^{*} 105$ (Taggart et al., 1981) or as $L D H-5^{*} 90$ and $L D H-5^{*} 100$ (Osinov, 1984; Hamilton et al., 1989). The $L D H-5^{*} 100 / 100$ homotetramer is known to have a higher substrate efficiency (Henry \& Ferguson, 1985). The substitution of $L D H-5^{*} 105$ by $L D H-5^{*} 100$ took place in almost all populations accessible to carriers of the latter allele. $L D H-5^{*}$ has therefore been considered to be a phylogeographical marker locus (Hamilton et al., 1989); the faster moving allele, $L D H-5^{*} 105(100)$, occurs in at least 11 salmonid species and thus represents the plesiomorphic character state whereas the cathodic allele, $L D H-5^{*} 100(90)$, is confined to brown trout (Hamilton et al., 1989). Spanish (Garcia-Marin et al., 1991; Moran et al., 1991; Martinez et al., 1993), Greek (Karakousis \& Triantaphyllidis, 1990), French, i.e. Corsican, Mediterranean and western Atlantic drainages (Krieg \& Guyomard, 1985), Black Sea and Caspian Sea populations (Osinov, 1984) are either fixed for the allele $L D H-5^{*} 105(100)$ or at least exhibit high frequencies. In contrast, allele $L D H-5^{*} 100$ (90) is fixed or at least is very common in brown trout of North Atlantic origin, i.e. in accessible tributaries of the 
White, the Baltic and North Seas (Hamilton et al., 1989).

With the allele $L D H-5 * 100$ being obviously close to fixation in the Rhine drainage system, and with the LDH $-5^{*} 105$ being significantly more common in populations of the Danube drainage system, we infer a phylogenetic relationship between Danubian brown trout populations from southwest Germany and those from southeast Europe, rather than with those from the adjacent Rhenanian drainage system (northern Atlantic).

The discovery of affinities between Danubian brown trout populations of southwest Germany and the former Yugoslavia, and the uniformity of brown trout of Atlantic origin in DNA sequence variation of the control region of mitochondrial DNA (Bernatchez et al., 1992) support the present findings. One may expect that continued unabated stocking, using chiefly brown trout from Atlantic origin, continues to obscure the historic pattern of allele distribution.

\section{Acknowledgements}

Financial support from the Ministry of Environment, Baden-Württemberg, is gratefully acknowledged (Projekt 'Angewandte Ökologie', Förderkennzeichen 20-921501).

\section{References}

AEBERSOLD, P. B., WINANS, G. A., TEEL, D. J., MILNER, G. B. AND UTTER, F. M. 1987. Manual for starch gel electrophoresis: a method for the detection of genetic variation. NOAA Technical Report NMFS 61.

ALLENDORF, F. W., MITCHELL, N., RYMAN, N. AND STAHL, G. 1977. Isozyme loci in brown trout (Salmo trutta L.): detection and interpretation from population data. Hereditas, 86, 179-190.

ALLENDORF, F. W., RYMAN, N., STENNEK, A. AND STAHL, G. 1976. Genetic variation in Scandinavian brown trout (Salmo trutta L.): evidence of distinct sympatric populations. Hereditas, 83, 73-82.

BALON, E. K. 1968. Notes on the origin and evolution of trouts and salmon with special reference to the Danubian trouts. Věst.čsl.zeměd.Mus., 32, 1-21.

BARBAT-LETERRIER, A., GUYOMARD, R. AND KRIEG, F. 1989. Introgression between introduced domesticated strains and Mediterranean native populations of brown trout (Salmo trutta L.). Aquat. Living Resour, , 2, 215-223.

BERNATCHEZ, L., GUYOMARD, R. AND BONHOMME, F. 1992. DNA sequence variation of the mitochondrial control region among geographically and morphologically remote European brown trout populations. Mol. Ecol., 1, 161-173.
BORCHERDT, C. 1991. Bundesrepublik Deutschland. 5. BadenWürttemberg: eine geographische Landeskunde. Wissenschaftliche Buchgesellschaft, Darmstadt

CHAKRABORTY, R. AND LEIMAR, o. 1987. Genetic variation within a subdivided population. In: Ryman, N. and Utter, F. (eds) Population Genetics and Fisheries Management, pp. 89-120. University of Washington Press, Seattle and London.

DAYE, P. G. AND GARSIDE, E. T. 1979. Development and survival of embryos and alevins of the Atlantic salmon, Salmo salar, continuously exposed to acidic levels of $\mathrm{pH}$, from fertilization. Can. J. Zool., 57, 1713-1718.

FELSENSTEIN, 3. 1989. PHYLIP: Phylogeny Inference Package (version 3.2). Cladistics, 5, 164-166.

FERGUSON, A. 1989. Genetic differences among brown trout, Salmo trutta, stocks and their importance for the conservation and management of the species. Freshwater Biol., 21, 35-46.

GARCIA-MARIN, J. L., JORDE, P. E., RYMAN, N., UTTER, F. AND PLA, C. 1991. Management implications of genetic differentiation between native and hatchery populations of brown trout (Salmo trutta) in Spain. Aquaculture, 95, 235-249.

GUYOMARD, R. AND KRIEG, F. 1983. Electrophoretic variation in six populations of brown trout (Salmo trutta L.). Can. J. Genet. Cytol., 25, 403-413.

HAMILTON, K. E., FERGUSON, A., TAGgART, J. B., TOMASSON, T., WALKER, A. AND FAHY, E. 1989. Post-glacial colonization of brown trout, Salmo trutta L.: $L d h-5$ as a phylogeographic marker locus. J. Fish Biol., 35, 651-664.

HANTKE, R. 1993. Flußgeschichte Mitteleuropas. Ferdinand Enke Verlag, Stuttgart

HARRIS, H. AND HOPKINSON, D. A. 1976. Handbook of Enzyme Electrophoresis in Human Genetics. American Elsevier, New York.

HAUSER, L., BEAUMONT, A. R., MARSHALL, G. T. H. AND WYATT, R. J. 1991. Effects of sea trout stocking on the population genetics of landlocked brown trout, Salmo trutta L., in the Conwy River system, North Wales, U.K. J. Fish Biol., 39 (Suppl. A), 109-116.

HENRY, T. AND FERGUSON, A. 1985. Kinetic studies on the lactate dehydrogenase (LDH-5) isozymes of the brown trout, Salmo trutta L. Comp. Biochem. Physiol., 82B, 95-98.

HINDAR, K., RYMAN, N. AND UTTER, F. 1991. Genetic effects of cultured fish on natural populations. Can. J. Fish. Aquat. Sci., 48, 945-957.

KARAKOUSIS, Y. AND TRIANTAPHYLLIDIS, C. 1990. Genetic structure and differentiation among Greek brown trout (Salmo trutta L.) populations. Heredity, 64, 297-304.

KRIEG, F. AND GUYOMARD, R. 1985. Population genetics of French brown trout (Salmo trutta L.): large geographical differentiation of wild populations and high similarity of domesticated stocks. Génét. Sél. Évol., 17, 225-242.

LELEK, A. 1988. Vorkommen, Taxonomie und Maßnahmen zur Erhaltung der Forelle Salmo trutta labrax Pallas 1811 in der NO-Türkei. Courier Forsch.-Inst. Senckenberg, 101, $1-44$.

MADER, M. 1978. Die Flußgeschichte des Neckars und das Wandern des Albtraufs. Veröff. Naturschutz Landschaftspflege Bad.- Württ., 47/48, 443-507. 
MARTINEZ, P., ARIAS, J., CASTRO, J. AND SANCHEZ, L. 1993. Differential stocking incidence in brown trout (Salmo trutta) populations from Northwestern Spain. Aquaculture, 114, 203-216.

MOLLER HANSEN, M., LOESCHCKE, V., RASMUSSEN, G. AND SIMONSEN, v. 1993. Genetic differentiation among Danish brown trout (Salmo trutta) populations. Hereditas, 118, 177-185.

MORAN, P., PENDAS, A. M., GARCIA-VAZQUEZ, E. AND IZQUIERDO, J. 1991. Failure of a stocking policy, of hatchery reared brown trout, Salmo trutta L., in Asturias, Spain, detected using LDH-5* as a genetic marker. J. Fish Biol., 39, $117-121$.

MULler, H. 1956. Die Forellen. Die einheimischen Forellen und ihre wirtschaftliche Bedeutung. Neue Brehmbücherei 164. A. Ziemsen Verlag, Wittenberg, Lutherstadt.

NEI, M. 1978. Estimation of average heterozygosity and genetic distance from a small number of individuals. Genetics, 89, 583-590.

NELSON, K. AND SOULE, M. 1987. Genetical conservation of exploited fishes. In: Ryman, N. AND Utter, F. (eds) Population Genetics and Fisheries Management, pp. 345-368. University of Washington Press, Seattle and London.

osiNOV, A. G. 1984. Zoogeographical origins of brown trout, Salmo trutta (Salmonidae): data from biochemical genetic markers. J. Ichthyol., 24, 10-23.
RYMAN, N. 1983. Patterns of distribution of biochemical genetic variation in salmonids: differences between species. Aquaculture, 33, 1-21.

RYMAN, N., ALLENDORF, F. W. AND STAHL, G. 1979. Reproductive isolation with little genetic divergence in sympatric populations of brown trout (Salmo trutta), Genetics, 92, 247-262.

SCHAAL, B. A. AND ANDERSON, w. w. 1974. An outline of techniques for starch gel electrophoresis of enzymes from American oyster Crassostrea virginica Gmelin. Georgia Marine Science Center Technical Report 74-3.

SHAKLEE, J. B., ALLENDORF, F. W., MORIZOT, D. C. AND WHITT, G. S. 1990. Gene nomenclature for protein-coding loci in fish. Trans. Am. Fish. Soc., 119, 2-15.

SKAALA, O. 1992. Genetic population structure of Norwegian brown trout. J. Fish Biol., 41, 631-646.

TAGGART, J. B. AND FERGUSON, A. 1986. Electrophoretic evaluation of a supplemental stocking programme for brown trout, Salmo trutta L. Aquaculture Fish. Manage., 17, 155-162.

TAGGART, J., FERGUSON, A. AND MASON, F. M. 1981. Genetic variation in Irish populations of brown trout (Salmo trutta L.): electrophoretic analysis of allozymes. Comp. Biochem. Physiol., 69B, 393-412.

WAGNER, G. 1963. Danubische und rheinische Abtragung im Neckar- und Tauberland. Ber. dt. Landesk., 31, 1-11. 